\title{
The Romanomermis iyengari parasite for Anopheles pseudopunctipennis suppression in natural habitats in Oaxaca State, Mexico
}

\author{
Alberto Santamarina Mijares, ${ }^{1}$ Rafael Pérez Pacheco, ${ }^{2}$ Sabino Honorio \\ Tomás Martínez, ${ }^{2}$ Luis Enrique Cantón, ${ }^{2}$ and Gonzalo Flores Ambrosio ${ }^{2}$
}

\begin{abstract}
In September and November 1996 Romanomermis iyengari Welch, a parasite of larval mosquitoes, was released in 44 natural larval habitat sites of Anopheles pseudopunctipennis Theobald in an attempt to reduce the larval populations of this important malaria vector. The selected treatment sites ranged in size from 5 to $500 \mathrm{~m}^{2}$. The study was carried out in Pochutla District of Oaxaca State, on the Pacific coast of Mexico.

Chemical pesticides to reduce vector populations have been the principal tool in malaria suppression campaigns. However, the excessive use of these chemicals has created pesticide resistance and other serious collateral problems. Therefore, a biological control project using agents that are pathogens of Anopheles larvae was initiated in 1996. The principal objective was to establish mass rearing capacities for $\mathrm{R}$. iyengari. Detailed methodology for rearing and introducing these nematodes into mosquito larval habitats was established at the National Polytechnic Institute of Oaxaca State. Before application of the parasites to larval habitats, site characteristics were determined, including size, depth, aquatic vegetation, salinity, $p H$, conductivity, temperature, and pretreatment larval density. With a compressed air sprayer, infective mermithid parasites were released at rates of either 2000 or $3000 / \mathrm{m}^{2}$, and the parasites produced high levels of infection. Anopheles populations were sampled $72 \mathrm{~h}$ posttreatment, and the larvae obtained were taken to the laboratory and examined through microscopic dissection to determine infection levels and mean parasitism. Nematode parasitism ranged from 85 to $100 \%$ at all the treatment sites, even though no previous information concerning field parasitism of An. pseudopunctipennis by R. iyengari has been reported. In addition, a significant reduction of mosquito larval density at the treatment sites was found five days after the nematode application. Levels of parasitism were indicative of the number of mosquito larvae killed by the treatment since infected larvae never progressed to the pupal stage. Results from sampling nine of the sites 2 months after the initial application of nematodes indicated that a high number of mosquito larvae were infected by parasites that had emerged from eggs previously deposited in the stratum. This work suggests the potential of this mermithid to reduce An. pseudopunctipennis populations in Oaxaca State.
\end{abstract}

1 Instituto de Medicina Tropical "Pedro Kouri," Autopista Novia del Mediodía km 6, e/ Autopista Nacional y Carretera Central, La Lisa, C.P. 11500, Ciudad de la Habana, Cuba. Telephone: 53-7-220650/-0651. E-mail: santamarina@ipk.sld.cu

2 Instituto Politécnico Nacional, Centro Interdisciplinario de Investigación para el Desarrollo Integral Regional, Oaxaca, Mexico.
Among the states in Mexico with the highest incidence of malaria are Chiapas, Oaxaca, Sinaloa, Michoacán, Guerrero, and Nayarit. Anopheles albimanus Wiedeman and Anopheles pseu- dopunctipennis Theobald are the principal vectors of malaria in the country. Anopheles vestitipennis Dyar and Knab is considered a secondary vector. Natural populations of An. pseudopuncti- 
pennis can be found in many malariaendemic areas of Mexico, and it is the principal malaria vector of the Pacific coastal states of the country. Vector control by the National Campaign to Eradicate Malaria has been very difficult to achieve in these states (1).

Applying pesticides for malaria vector and disease suppression has not satisfactorily reduced malaria cases. Such insecticides as DDT, malathion, and Abate have been used in Oaxaca State. However, their use has created serious problems, including the development of pesticide resistance, environmental pollution, the killing of nontarget organisms, alterations to ecosystems, and high expenditures for the newer chemical products. For these reasons alternative methods of vector suppression have been developed. The use of natural pathogenic and parasitic agents of Anopheles larvae has been considered. Extensive research on the feasibility of using biological control agents against malaria vectors has shown the potential usefulness of Romanomermis iyengari Welch, a mermithid nematode and an obligate parasite of mosquito larvae (2). The mermithid $R$. iyengari was originally found as a juvenile parasitic form in the hemocoel of Anopheles subpictus Grassi from Bangalore, India (3). It was released in rice paddy fields to control mosquito larvae and was observed parasitizing larvae of both Culex spp. and Anopheles spp. at rates of 92 to $98 \%$ (4). In waters with An. albimanus, Culex nigripalpus Theobald, and Culex quinquefasciatus Say mosquito larvae, the application of 1000 parasites $/ \mathrm{m}^{2}$ of surface area resulted in infection levels of 100, 85, and $75 \%$ respectively (5). Laboratory and field tests demonstrated the pathogenic action of $R$. iyengari in larvae of Aedes taeniorhynchus Wiedemann, a salt marsh mosquito. Parasitism levels from 71 to $100 \%$ were produced (6). Field studies also showed $R$. iyengari became permanently established and continued to reinfect mosquito larvae without additional applications. Safety tests were conducted in the laboratory and under field conditions using single massive doses of $R$. iyengari administered to selected nontarget organisms, both invertebrates and vertebrates. Penetration was attempted but no significant effect on nontarget organisms was observed. $R$. iyengari is suggested to be as safe to humans and other organisms as are the other mermithid nematodes used for vector control (7).

This study reports the results obtained in 44 natural larval habitat sites of An. pseudopunctipennis with the application of $R$. iyengari cultures produced at the mass rearing unit located in Oaxaca State, Mexico.

\section{MATERIALS AND METHODS}

The $R$. iyengari mosquito parasite was mass produced to treat $2395 \mathrm{~m}^{2}$ of An. pseudopunctipennis breeding area. The basic mass rearing procedure required the exposure of 200000 secondinstar $C x$. quinquefasciatus larvae to 1 million parasitic nematodes (1:5 ratio) every 10 days for 6 months. This method produced an average of $68.5 \mathrm{~g}$ of postparasitic nematodes and a total of 120 cultures over each 10-day period. The desired inoculum of parasitic nematodes (the water from the flooded nematode cultures) was carefully collected in a common container $(200 \mathrm{~mL})$. The volume of decanted water containing the parasitic nematodes was then determined by volumetric dilution previously described (8). Seven days after exposure, host larvae were removed from each rearing tray $(60 \times 40 \times 12 \mathrm{~cm})$, concentrated, washed, and placed in smaller nematode-collecting trays $(39.5 \times 27 \times 6 \mathrm{~cm})$. After emergence the nematodes were collected, washed, and placed in plastic containers $(18 \times 12 \times 6 \mathrm{~cm})$ containing clean sterile sand ( $2 \mathrm{~cm}$ deep) covered to a depth of $1 \mathrm{~cm}$ with distilled water. Then the water was removed after $2 \mathrm{~h}$ and the cultures were covered. After about 6 weeks the cultures were used for field applications.

The field applications to evaluate the potential suppression of mosquito larvae populations by $R$. iyengari were conducted from 1 September to $15 \mathrm{No}$ vember 1996. Forty-four An. pseudopunctipennis larval habitats were identified in the San Bernardino and San Isidro localities (between $100 \mathrm{~m}$ to $150 \mathrm{~m}$ above sea level) and treated with $R$. iyengari at a rate of 2000 $3000 / \mathrm{m}^{2}$ of water surface. The bodies of water ranged in area from $5 \mathrm{~m}^{2}$ to $500 \mathrm{~m}^{2}$. Pretreatment examination several hours prior to the application of nematodes indicated a high population of An.pseudopunctipennis 1st to 4th instars at each site. Numerous insect predators were present in each habitat, including immature and adult stages of Hemiptera, Belostoma apache Kirk and Pelocoris femoratus Barber; Odonata, suborders Anisoptera and $\mathrm{Zy}$ goptera; and Coleoptera, Thermonectus circumscriptus Latreille and Tropisternus lateralis $\mathrm{F}$. The sites varied greatly in size, shape, depth, and amount of floating and emergent vegetation (filamentous algae). Physical and chemical parameters of the water were calculated, including $\mathrm{pH}$, salinity, conductivity, and temperature.

A total of 370 cultures containing eggs of $R$. iyengari produced at the mass rearing unit were transported to malaria-endemic areas of Pochutla District. Mermithid cultures (240) were flooded with distilled water to obtain parasitic nematodes for field release at the 44 selected sites. The number of infective-stage $R$. iyengari per unit volume of water was determined by volumetric dilution. The cultures provided sufficient inoculum (250 liters) and 69450000 preparasites. Final dilutions were made prior to release using water from the test sites. Parasitic larvae were applied directly over the entire water surface using a compressed air sprayer (H. D. Hudson Manufacturing Company, Chicago, IL) at a dosage rate of 2000 or $3000 / \mathrm{m}^{2}$ of surface area and at an approximate pressure of 2 atmospheres, as previously described (9). (Larval nematodes were released at a dosage rate of $3000 / \mathrm{m}^{2}$ at sites $12,14,19,29,30,31$, and 32 due to the vegetation present.) The water temperature at the time of application varied from 26 to $33^{\circ} \mathrm{C}$. 
Mosquito larvae (1st to 4 th instars) were sampled $72 \mathrm{~h}$ posttreatment from the 44 treated sites (100 larvae per site) and examined under a compound microscope to determine infection levels and mean parasitism. Two control sites were established to compare the results. In addition, mosquito larvae abundance was determined at the sites 5 days after the first application using a larval net $20 \mathrm{~cm}$ in diameter and $20 \mathrm{~cm}$ in depth with a handle of $2 \mathrm{~m}$ (10).

Data obtained did not show a normal distribution, so prior statistical analysis data were transformed by the square root of $x$. Analysis of variance (ANOVA) and the Duncan multiplerange test were used to compare mean infections. The percentage reduction in mosquito larvae density at the 44 sites was evaluated through the following formula (11) where:

$\%$ reduction $=$

$100-\left(\left(\mathrm{T}_{2} / \mathrm{T}_{1} \times\left(\mathrm{C}_{1} / \mathrm{C}_{2}\right) \times 100\right)\right.$

and where $C_{1}$ and $T_{1}$ and $C_{2}$ and $T_{2}$ are the abundance of larvae in the control (C) and treated (T) sites before $\left(_{1}\right)$ and after $\left(_{2}\right)$ applications, respectively.

\section{RESULTS}

Ecological characteristics of the 44 study sites are shown in Table 1. In this study An. pseudopunctipennis was found to be susceptible to infection by $R$. iyengari when application rates were either $2000 / \mathrm{m}^{2}$ or $3000 / \mathrm{m}^{2}$. After applications of infective parasites at a dosage rate of $2000 / \mathrm{m}^{2}, 21$ of the 44 sites $(11,13,15,16,17,18,21,22$, $23,24,25,26,27,33,35,36,38,39,40$, 41, 42, and 44) produced An. pseudopunctipennis with mean levels of infection ranging from 3.2 to 9.8 and $100 \%$ parasitism (Table 2). Although all instars (1st through 4th) were present at these sites, the majority of larvae collected were 1st and 2nd instars, and the highest mean incidence of parasitism occurred in these instars. Parasitism was somewhat lower-85 to $94 \%$-at a group of 16 other sites $(1,2$, $3,4,5,6,7,8,9,10,20,22,28,34,37$,

TABLE 1. Ecological characteristics of 44 natural mosquito larval habitat sites treated with Romanomermis iyengari and two untreated control sites, Oaxaca State, Mexico, 1996

\begin{tabular}{|c|c|c|c|c|c|c|c|}
\hline Site & $\begin{array}{l}\text { Area } \\
\left(\mathrm{m}^{2}\right)\end{array}$ & $\begin{array}{l}\text { Depth } \\
(\mathrm{cm})\end{array}$ & Vegetation & $\mathrm{pH}$ & $\begin{array}{c}\text { Salinity } \\
\text { (mol) }\end{array}$ & $\begin{array}{c}\text { Conductivity } \\
(\mathrm{ms} / \mathrm{cm})\end{array}$ & $\begin{array}{l}\text { Temp } \\
\left({ }^{\circ} \mathrm{C}\right)\end{array}$ \\
\hline 1 & 12 & 25 & algae & 7.6 & 0.40 & 1 & 26 \\
\hline 2 & 12 & 27 & algae & 7.7 & 0.40 & 1 & 26 \\
\hline 3 & 42 & 32 & algae & 7.7 & 0.40 & 1 & 26 \\
\hline 4 & 18 & 29 & algae & 7.7 & 0.40 & 1 & 26 \\
\hline 5 & 40 & 32 & algae & 7.8 & 0.38 & 1 & 32 \\
\hline 6 & 46 & 38 & algae & 8.0 & 0.39 & 1 & 32 \\
\hline 7 & 11 & 34 & algae & 8.6 & 0.24 & 1 & 32 \\
\hline 8 & 114 & 68 & algae & 8.5 & 0.25 & 1 & 31 \\
\hline 9 & 62 & 55 & algae & 8.7 & 0.24 & 1 & 32 \\
\hline 10 & 75 & 59 & algae & 8.0 & 0.30 & 1 & 33 \\
\hline 11 & 26 & 35 & algae & 7.8 & 0.28 & 1 & 28 \\
\hline 12 & 11 & 29 & algae & 7.2 & 0.28 & 1 & 29 \\
\hline 13 & 10 & 19 & algae & 8.7 & 0.21 & 1 & 28 \\
\hline 14 & 28 & 22 & algae & 8.2 & 0.22 & 1 & 28 \\
\hline 15 & 56 & 44 & algae & 7.7 & 0.23 & 1 & 30 \\
\hline 16 & 24 & 19 & algae & 7.8 & 0.22 & 1 & 27 \\
\hline 17 & 62 & 45 & algae & 8.2 & 0.22 & 1 & 27 \\
\hline 18 & 80 & 75 & algae & 7.9 & 0.23 & 1 & 27 \\
\hline 19 & 6 & 16 & algae & 8.1 & 0.23 & 1 & 28 \\
\hline 20 & 8 & 17 & algae & 7.6 & 0.23 & 1 & 28 \\
\hline 21 & 216 & 84 & algae & 8.9 & 0.30 & 1 & 29 \\
\hline 22 & 19 & 29 & algae & 7.8 & 0.5 & 1 & 28 \\
\hline Control & 42 & 31 & algae & 7.7 & 0.35 & 1 & 28 \\
\hline 23 & 5 & 17 & algae & 8.7 & 0.27 & 1 & 29 \\
\hline 24 & 30 & 38 & algae & 7.5 & 0.32 & 1 & 30 \\
\hline 25 & 56 & 44 & algae & 7.4 & 0.33 & 1 & 30 \\
\hline 26 & 36 & 33 & algae & 7.5 & 0.33 & 1 & 32 \\
\hline 27 & 60 & 49 & algae & 7.5 & 0.33 & 1 & 31 \\
\hline 28 & 27 & 25 & algae & 7.6 & 0.40 & 1 & 30 \\
\hline 29 & 40 & 37 & algae & 7.4 & 0.82 & 1 & 31 \\
\hline 30 & 10 & 15 & algae & 6.9 & 0.81 & 1 & 31 \\
\hline 31 & 36 & 29 & algae & 7.6 & 0.75 & 1 & 30 \\
\hline 32 & 72 & 68 & algae & 7.7 & 0.79 & 1 & 31 \\
\hline 33 & 11 & 18 & algae & 7.4 & 0.68 & 1 & 30 \\
\hline 34 & 16 & 19 & algae & 7.0 & 0.68 & 1 & 31 \\
\hline 35 & 15 & 29 & algae & 7.4 & 0.67 & 1 & 30 \\
\hline 36 & 19 & 39 & algae & 7.2 & 0.68 & 1 & 30 \\
\hline 37 & 36 & 49 & algae & 7.2 & 0.67 & 1 & 30 \\
\hline 38 & 78 & 70 & algae & 7.4 & 0.65 & 1 & 30 \\
\hline 39 & 12 & 65 & algae & 7.4 & 0.58 & 1 & 30 \\
\hline 40 & 44 & 59 & algae & 7.4 & 0.61 & 1 & 30 \\
\hline 41 & 38 & 48 & algae & 7.2 & 0.60 & 1 & 29 \\
\hline 42 & 30 & 65 & algae & 7.9 & 0.63 & 1 & 28 \\
\hline 43 & 50 & 58 & algae & 7.9 & 0.68 & 1 & 29 \\
\hline 44 & 500 & 82 & algae & 8.5 & 0.64 & 1 & 30 \\
\hline Control & 38 & 47 & algae & 8.2 & 0.63 & 1 & 30 \\
\hline
\end{tabular}

and 43), with mean infections of 1.2 to 2.8 (Table 2). The older larvae of $A n$. pseudopunctipennis in these 16 sites proved to be less susceptible than younger larvae, although these larvae (last instars) also became infected. A comparison of mean values of infection by one-way ANOVA and the
Duncan multiple-range test showed differences between those two groups of sites $(F=465.2 ; P<0.005)$, with the highest infection means occurring in the first group of sites.

At a third group of 7 sites $(12,14$, $19,29,30,31$, and 32) dosage rates of $3000 / \mathrm{m}^{2}$ were used because aquatic 
TABLE 2. Mean infections and percentage of parasitism of Anopheles pseudopunctipennis larvae at 44 sites treated with Romanomermis iyengari, Oaxaca State, Mexico, 1996

\begin{tabular}{|c|c|c|}
\hline $\begin{array}{c}\text { Site } \\
\text { number }\end{array}$ & $\begin{array}{c}\text { Mean } \\
\text { infections }^{a}\end{array}$ & $\begin{array}{c}\text { Parasitism } \\
(\%)\end{array}$ \\
\hline 1 & $1.7 \mathrm{~b}$ & 92 \\
\hline 2 & $2.5 \mathrm{~b}$ & 90 \\
\hline 3 & $2.8 \mathrm{~b}$ & 90 \\
\hline 4 & $2.0 \mathrm{~b}$ & 88 \\
\hline 5 & $1.7 \mathrm{~b}$ & 90 \\
\hline 6 & $1.8 \mathrm{~b}$ & 90 \\
\hline 7 & $1.5 \mathrm{~b}$ & 85 \\
\hline 8 & $1.2 \mathrm{~b}$ & 85 \\
\hline 9 & $1.2 \mathrm{~b}$ & 85 \\
\hline 10 & $2.6 \mathrm{~b}$ & 94 \\
\hline 11 & $3.2 \mathrm{a}$ & 100 \\
\hline 12 & $-c$ & - \\
\hline 13 & $6.8 \mathrm{a}$ & 100 \\
\hline 14 & $-c$ & - \\
\hline 15 & $3.5 \mathrm{a}$ & 100 \\
\hline 16 & $4.3 \mathrm{a}$ & 100 \\
\hline 17 & $4.0 \mathrm{a}$ & 100 \\
\hline 18 & $3.4 \mathrm{a}$ & 100 \\
\hline 19 & $-c$ & - \\
\hline 20 & $2.5 \mathrm{~b}$ & 89 \\
\hline 21 & $3.4 \mathrm{a}$ & 100 \\
\hline 22 & $2.2 \mathrm{~b}$ & 94 \\
\hline 23 & $9.8 \mathrm{a}$ & 100 \\
\hline 24 & $5.0 \mathrm{a}$ & 100 \\
\hline 25 & $4.8 \mathrm{a}$ & 100 \\
\hline 26 & $3.2 \mathrm{a}$ & 100 \\
\hline 27 & $6.0 \mathrm{a}$ & 100 \\
\hline 28 & $2.5 \mathrm{~b}$ & 92 \\
\hline 29 & $-c$ & - \\
\hline 30 & $-c$ & - \\
\hline 31 & $-c$ & - \\
\hline 32 & $-c$ & - \\
\hline 33 & $4.2 \mathrm{a}$ & 100 \\
\hline 34 & $2.0 \mathrm{~b}$ & 90 \\
\hline 35 & $8.8 \mathrm{a}$ & 100 \\
\hline 36 & $3.8 \mathrm{a}$ & 100 \\
\hline 37 & $2.4 \mathrm{~b}$ & 88 \\
\hline 38 & $6.0 \mathrm{a}$ & 100 \\
\hline 39 & $5.4 \mathrm{a}$ & 100 \\
\hline 40 & $4.7 \mathrm{a}$ & 100 \\
\hline 41 & $9.2 \mathrm{a}$ & 100 \\
\hline 42 & $3.2 \mathrm{a}$ & 100 \\
\hline 43 & $2.4 \mathrm{~b}$ & 88 \\
\hline 44 & $3.9 \mathrm{a}$ & 100 \\
\hline
\end{tabular}

a Means of a first group (those followed by the letter "a") were significantly different $(P<0.005)$ from means of a second group (those followed by the letter "b"). At a third group of sites (those identified with the letter " $c$ "), an application rate of $3000 / \mathrm{m}^{2}$ had been used, and mosquito larvae were completely eliminated $72 \mathrm{~h}$ posttreatment.

vegetation (algae) was prominent. At those 7 sites mosquito larvae populations were found to be completely eliminated $72 \mathrm{~h}$ after the release of the infective parasites (Table 2). The high mortality of the Anopheles larvae is believed to result from multiple infections, which produce the early death of the hosts and parasites, especially in early instars. This reduces the chance that the parasites will become established.

All the 44 sites produced high levels of infection at both doses $\left(2000 / \mathrm{m}^{2}\right.$ and $3000 / \mathrm{m}^{2}$ ) though the host populations were very different at the time of treatment. The results demonstrated that $R$. iyengari parasites efficiently locate and parasitize Anopheles larvae, that the amounts of vegetation (algae) had little influence on the levels of parasitism when the dosage rate was $3000 / \mathrm{m}^{2}$, and that levels of parasitism can be increased by increasing the dose of nematodes. The data also suggest that doses in excess of $3000 / \mathrm{m}^{2}$ may produce many cases of multiple infections, which result in early death of both hosts and parasites.

A small increase in mosquito larvae density was observed at the two control sites (Table 3). Nontarget predator populations were sampled $72 \mathrm{~h}$ posttreatment by collecting several samples from each treated site. Large concentrations of insect predators were found. Results from sampling nine of the sites $(11,13,15,16,18,23,25,26$, and 33) 2 months after treatment indicated that a high number of mosquito larvae were infected by parasites that had emerged from eggs previously deposited in the stratum. This demonstrated that $R$. iyengari was established (data not reported numerically).

\section{DISCUSSION}

Many authors have demonstrated high levels of parasitic infection by $R$. iyengari of such mosquito larval species as Aedes spp., Anopheles spp., and Culex spp (12). However, previous information concerning field parasitism of An. pseudopunctipennis by $R$. iyengari has not been reported. This field test data demonstrated that $R$. iyengari is a potential natural parasitic agent able to reduce An. pseudopunc- tipennis larval populations in Oaxaca State. Results of treatment at all 44 sites showed that larval populations of An. pseudopunctipennis could be substantially reduced. At 7 of the sites (12, $14,19,29,30,31$, and 32) no larvae could be found $72 \mathrm{~h}$ after treatment. In these sites dense vegetation (algae) contributed to a decreased contact between parasites and mosquito larvae, so a higher dosage rate of $3000 / \mathrm{m}^{2}$ was used. The reduction in host numbers posttreatment was attributed to the early death of many 1st- and 2ndinstar larvae due to multiple infections by the nematodes. These results suggest that a higher percentage of parasitism and subsequent host mortality could be achieved by simply increasing the number of nematode larvae released. Nevertheless, this high level of infection at the 7 sites is presumed to be unfavorable for nematode establishment, since host populations were drastically reduced.

The high susceptibility of An. pseudopunctipennis larvae to infection by mermithid larvae can be partially explained by the fact that mosquito larvae adopt a horizontal position below the water surface, thereby facilitating their invasion by the preparasite mermithid larvae, which exhibit negative geotropism (13).

Differences in the level of parasitism between the first and second groups of sites were attributed primarily to the higher populations of younger-instar An. pseudopunctipennis in the first group. Levels of infection were lowest in the $3 \mathrm{rd}$ and 4 th instars at the second group of sites. This finding is supported by laboratory data that observed that early instars were more susceptible than older instars $(2,6,14)$. This phenomenon seems to be related to the thickness of the mosquito larvae cuticle (15). Probably the lower infection levels in the second group of sites were also due to the water current at these sites, whose velocity was $1 \mathrm{~m} / 4.84$ seconds.

When the population of insect predators at the sites treated at a rate of $2000 / \mathrm{m}^{2}$ was sampled $72 \mathrm{~h}$ posttreatment, the predators were still 
TABLE 3. Percentage reduction in Anopheles pseudopunctipennis larval populations 5 days posttreatment, Oaxaca State, Mexico, 1996

\begin{tabular}{|c|c|c|c|}
\hline Site number & $\begin{array}{l}\text { Larval density } \\
\text { pretreatment per } \mathrm{m}^{2}\end{array}$ & $\begin{array}{l}\text { Larval density } \\
\text { posttreatment per } \mathrm{m}^{2}\end{array}$ & $\%$ reduction \\
\hline 1 & 261 & 20 & 94 \\
\hline 2 & 370 & 25 & 95 \\
\hline 3 & 244 & 28 & 91 \\
\hline 4 & 244 & 40 & 87 \\
\hline 5 & 178 & 18 & 92 \\
\hline 6 & 130 & 15 & 90 \\
\hline 7 & 71 & 14 & 86 \\
\hline 8 & 152 & 25 & 87 \\
\hline 9 & 150 & 27 & 85 \\
\hline 10 & 144 & 8 & 95 \\
\hline 11 & 148 & 6 & 98 \\
\hline 12 & 52 & 0 & 100 \\
\hline 13 & 182 & 4 & 98 \\
\hline 14 & 326 & 0 & 100 \\
\hline 15 & 181 & 4 & 98 \\
\hline 16 & 223 & 2 & 99 \\
\hline 17 & 479 & 5 & 99 \\
\hline 18 & 563 & 5 & 99 \\
\hline 19 & 1053 & 0 & 100 \\
\hline 20 & 132 & 15 & 90 \\
\hline 21 & 149 & 2 & 98 \\
\hline 22 & 397 & 23 & 95 \\
\hline Control & 355 & 371 & - \\
\hline 23 & 895 & 2 & 100 \\
\hline 24 & 643 & 3 & 100 \\
\hline 25 & 1496 & 4 & 100 \\
\hline 26 & 6105 & 3 & 100 \\
\hline 27 & 849 & 5 & 100 \\
\hline 28 & 792 & 40 & 96 \\
\hline 29 & 189 & 0 & 100 \\
\hline 30 & 676 & 0 & 100 \\
\hline 31 & 248 & 0 & 100 \\
\hline 32 & 181 & 0 & 100 \\
\hline 33 & 981 & 8 & 99 \\
\hline 34 & 2128 & 8 & 100 \\
\hline 35 & 1551 & 7 & 100 \\
\hline 36 & 3366 & 2 & 100 \\
\hline 37 & 599 & 75 & 90 \\
\hline 38 & 1782 & 2 & 100 \\
\hline 39 & 726 & 6 & 100 \\
\hline 40 & 709 & 8 & 99 \\
\hline 41 & 338 & 5 & 99 \\
\hline 42 & 302 & 4 & 99 \\
\hline 43 & 237 & 18 & 94 \\
\hline 44 & 249 & 7 & 99 \\
\hline Control & 340 & 395 & - \\
\hline
\end{tabular}

there and were not parasitized or affected by the nematode larvae. Examination $72 \mathrm{~h}$ posttreatment of the sites treated at a rate of $3000 / \mathrm{m}^{2}$ also indicated the presence of a population of nontarget predators.

The results indicated that the water quality in the test sites was within the acceptable ranges for use of this parasite and that such factors as the levels of temperature, $\mathrm{pH}$, salinity, and conductivity had no detectable adverse effects on the nematode-egg hatch or on the viability and infectivity of the nematode larvae. Moreover, the size of the treatment sites did not have a negative effect on the levels of infection.

A marked reduction in mosquito larvae density was observed at all the sites treated with $R$. iyengari nematode larvae. Data obtained from field bioassay as well as other reported data (16) have indicated that the small increases in the mosquito larvae populations at the two control sites was due to the continual oviposition of eggs and the hatching of new larvae. The examination of mosquito larvae from 9 of the sites 2 months after the initial nematode applications showed the capacity of $R$. iyengari to become established in this field situation (17). The natural populations of An. pseudopunctipennis larvae were drastically reduced or even eliminated entirely within $72 \mathrm{~h}$ when the application rate was $3000 / \mathrm{m}^{2}$.

Among the other conclusions that can be drawn from this research are:

a) An. pseudopunctipennis is highly susceptible to parasitism by $R$. iyengari under natural field conditions and that natural populations of these larvae, especially younger larvae, can be reduced.

b) Natural populations of An. pseudopunctipennis larvae can be completely killed within $72 \mathrm{~h}$ by increasing the dose of nematodes to $3000 / \mathrm{m}^{2}$.

c) Older larvae of An. pseudopunctipennis exposed to $R$. iyengari were infected but proved to be less susceptible to parasitism than younger larvae.

d) The levels of water temperature, $\mathrm{pH}$, salinity, conductivity, depth, and vegetation which were measured during this study were all within the acceptable ranges for the use of this parasite.

e) The nematode had become established at 9 sites monitored 2 months after the initial applications.

Acknowledgments. The authors wish to recognize the financial support of the Sistema de Investigación Benito Juárez. 


\section{REFERENCES}

1. Rodríguez López MH. Enfermedades tropicales en México. Diagnóstico, tratamiento y distribución geográfica. México, D.F., México: Instituto Nacional de Diagnóstico y Referencias Epidemiológicas en México; 1994:267-277.

2. Santamarina AM. Actividad parasitaria de Romanomermis iyengari (Nematoda: Mermithidae) en criaderos naturales de larvas de mosquitos. Miscelánea Zoológica 1994;17:59-65.

3. Welch H. Romanomermis iyengari species nov. Nematoda: Mermithidae Braun, 1883. Pilot Register of Zoology, Card no. 209.

4. Chandrahas RK, Rajagopalan PK. Mosquito breeding and the natural parasitism of larvae by a fungus Coelomomyces and mermithid nematode Romanomermis in paddy fields in Pondicherry. Indian J Med Res 1979; 69:63-70.

5. Santamarina AM, García IA, González RB. Valoración de la capacidad infectiva del nemátodo parásito Romanomermis iyengari $(\mathrm{Ne}-$ matoda: Mermithidae) en criaderos naturales de larvas de mosquitos. Rev Cub Med Trop 1993;45:128-131.

6. Santamarina AM, García IA, Rosabal JR, Solís AM. Release of Romanomermis iyengari (Nematoda: Mermithidae) to control Aedes taeniorhynchus (Diptera: Culicidae) in Punta del
Este, Isla de la Juventud. J Med Entomol 1996; 33:680-682.

7. Poinar GO. Entomogenous nematodes, a manual and host list of insect nematode associations. Leiden, Netherlands: E.J. Brill; 1975.

8. Petersen JJ, Willis OR. Procedures for the mass rearing of a mermithid parasite of mosquitoes. Mosquito News 1972;32:226-230.

9. Levy R, Murphy LJ Jr, Miller TW Jr. Effects of a simulated aerial spray on a mermithid parasite of mosquitoes. Mosquito News 1976;36: 498-501.

10. Dubitskij AM. Métodos de control biológico de los dípteros hematófagos en la URSS. T. 1. Acad. Csi. Kaz. SSR. Alma Ata, Ed. 11265 HC. 1978.

11. Lacey LA, Mulla MS. Field evaluation of difluobenzurón (Dimilin) against Simulium larvae. Mosquito News 1979;39:86-90.

12. Gajanana A, Kazmi SJ, Bheema Rao US, Sujuna SG, Chandrahas RK. Studies on a nematode parasite (Romanomermis sp.: Mermithid) of mosquito larvae isolated in Pondicherry. Indian J Med Res 1978;68:242-247.

13. Rojas W, Northup J, Gallo O, Montoya AE, Restrepo F, Nimnich M, et al. Reduction of malaria prevalence after introduction of Romanomermis culicivorax (Nematoda: Mermithi- dae) in larval Anopheles habitats in Colombia. Bull World Health Organ 1987;65(3):331-337.

14. Santamarina AM, Pérez RP. Efecto patogénico del nemátodo parásito Romanomermis iyengari (Nematoda: Mermithidae) en larvas del mosquito Aedes aeoypti (Diptera: Culicidae) en condiciones de laboratorio en el Estado de Oaxaca, México. Rev Cub Med Trop 1997;49: 93-97.

15. Petersen JJ. Comparative susceptibility of larval mosquitoes exposed by instar or in mixed populations to the nematode Romanomermis culicivorax. Journal of Nematology 1981;13: 228-229.

16. Petersen JJ, Willis OR. Experimental release of a mermithid nematode to control Anopheles mosquitoes in Louisiana. Mosquito News 1974;34:315-319.

17. Petersen JJ, Willis OR. Establishment and recycling of a mermithid nematode for the control of mosquitoe larvae. Mosquito News 1975; 35:526-532.

Manuscript received on 8 August 1997. Revised version accepted for publication on 7 December 1998.
RESUMEN

El parásito Romanomermis iyengari para la supresión de Anopheles pseudopunctipennis de sus hábitat naturales en el estado de Oaxaca, México
En septiembre y noviembre de 1996, Romanomermis iyengari Welch, parásito de larvas de mosquitos, fueron liberados en 44 lugares que servían de hábitat natural a larvas de Anopheles pseudopunctipennis Theobald con objeto de reducir las poblaciones larvarias de este importante vector de la malaria. Los lugares elegidos para el tratamiento variaron en tamaño de 5 a $500 \mathrm{~m}^{2}$. El estudio se llevó a cabo en el distrito de Pochutla en el Estado de Oaxaca, sobre la costa pacífica de México.

Los plaguicidas químicos que reducen las poblaciones del vector han sido el instrumento principal en las campañas para la supresión de la malaria. No obstante, el uso excesivo de estas sustancias químicas ha dado origen a resistencia y a otros problemas serios. Por consiguiente, en 1996 se inició un proyecto de control biológico basado en el uso de agentes que son patógenos para las larvas de Anopheles. El objetivo principal fue establecer un sistema para criar $R$. iyengari en grandes cantidades. En el Instituto Politécnico Nacional del estado de Oaxaca se estableció un método detallado para criar estos nematodos e introducirlos en los hábitat de las larvas de mosquitos. Antes de colocar los parásitos dentro de los hábitat de las larvas, se determinaron las características de los lugares, entre ellas su tamaño, profundidad, vegetación acuática, salinidad, $\mathrm{pH}$, conductividad, temperatura y densidad larvaria antes del tratamiento. Con un fumigador por compresión de aire se liberaron parásitos de los nematodos infectantes a razones de 2000 ó 3000 por $\mathrm{m}^{2}$ y los parásitos produjeron tasas de infestación elevadas. A las 72 horas de aplicarse el tratamiento se tomaron muestras de las poblaciones de Anopheles y las larvas así obtenidas se llevaron al laboratorio, donde se sometieron a disección y examen microscópico para determinar los niveles de infestación y la carga parasitaria promedio. La carga de parásitos osciló entre 85 y 100\% en todos los lugares donde se aplicó el tratamiento, a pesar de que no se habían notificado datos previamente sobre la carga parasitaria de An. pseudopunctipennis por $R$. iyengari en campo abierto. En los lugares tratados también se detectó una notable reducción de la densidad de las larvas de mosquitos a los 5 días de aplicarse los nematodos. La carga parasitaria fue indicación del número de larvas de mosquitos que murieron como consecuencia del tratamiento, ya que las larvas infestadas nunca llegaron a formar crisálidas. A juzgar por los resultados del muestreo de nueve de los lugares tratados 2 meses después de la aplicación inicial de nematodos, un gran número de las larvas de mosquitos fueron infectadas por parásitos que habían nacido de huevos que ya estaban depositados en la tierra. Este trabajo sugiere que este nematodo puede reducir las poblaciones de An. pseudopuctipennis en el Estado de Oaxaca. 